\title{
Blueberry Propagation by Minicuttings in Response to Substrates and Indolebutyric Acid Application Methods
}

\author{
Ronan C. Colombo ${ }^{1}$, Deived U. de Carvalho ${ }^{1}$, Maria A. da Cruz ${ }^{1} \&$ Sergio R. Roberto ${ }^{1}$ \\ ${ }^{1}$ Agricultural Research Center-Fruit Crops Laboratory, Londrina State University, Londrina, Brazil \\ Correspondence: Ronan C. Colombo, Agricultural Research Center, Londrina State University, Celso Garcia Cid \\ Road km 380, Londrina, PR, Brazil. Tel: 55-043-3371-4697. E-mail: ronancolombo@yahoo.com.br
}

Received: April 2, 2018

Accepted: June 25, $2018 \quad$ Online Published: August 15, 2018

doi:10.5539/jas.v10n9p450

URL: https://doi.org/10.5539/jas.v10n9p450

\begin{abstract}
The nursery plants supply is one of the most important factors that limites blueberries production in some areas, due to some propagation difficulties observed on this species. In this way, this study aimed to evaluate substrates and IBA application methods on 'Powderblue' blueberries (Vaccinium ashei) minicuttings rooting, as well as to verify the rooting development in different periods. The study was divided in two experiments. The first one aimed to evaluate 'Powderblue' blueberry minicuttings rooting in three substrates (pine bark, carbonized rice husk and vermiculite) in response to two indolebutyric acid (IBA) application methods: $50 \%$ alcohol solution and talc. The second experiment aimed to evaluate 'Powderblue' blueberry minicuttings rooting using the best substrate recorded in the first trial (pine bark) and two IBA application methods associated to three periods of rooting access, in order to obtain the ideal rooting period and root development. In the first experiment the rooting percentage presented significant difference among the substrates; the higher percentage of rooted minicuttings occurred in pine bark substrate $(68 \%)$. Regarding the methods used to IBA application, the talc method was more efficient to promote minicuttings rooting. In the second experiment, it was observed an increase in cutting rooting percentage from 55 to $84 \%$, according to the evaluated seasons; however, the IBA application method did not influence the rooting percentage. Therefore, to produce 'Powderblue' blueberry plants from minicuttings it is recommended to use pine bark as substrate and talc as method to IBA application, transplanting the nurseries at 110 days after planting.
\end{abstract}

Keywords: Vaccinium ashei, powderblue, rooting

\section{Introduction}

Blueberries (Vaccinium ashei) production is considered as a substantial crop in several countries, since the fruits are widely known by its nutraceutical properties. However, a limiting factor that difficult the crop expansion in new areas is the nursery production due to the difficulties on cuttings rooting, specially from the new cultivars that presents few propagation material available (González et al., 2000; Ostrolucká et al., 2004; Meiners et al., 2007; Trevisan et al., 2008; Fischer et al., 2012, 2013).

The traditional nursery system production consists in collect cuttings with 10 to $15 \mathrm{~cm}$ length, keeping two or three apical leaves and removing the basal ones. In general, for semihardwood cuttings, the leaves must be cut in half to avoid water loss and to facilitate the management (Fischer et al., 2008; Trevisan et al., 2008; Ristow et al., 2009; Marangon \& Biasi, 2013). An alternative to optimize the material available to nursery production is to use in vitro propagation protocols. There are several studies about this technique (Silva et al., 2006, 2007; Schuch et al., 2008); however, the in vitro propagation requires a complex installation and qualified professionals, increasing the seedlings production costs. As an alternative, the minicuttings propagation could be applied, since it requires less investiment and make a better use of propagation materials (Schuch et al., 2007; Pelizza et al., 2010; Fischer et al., 2013). Nevertheless, few studies are available concerning blueberries minicuttings propagation.

In addition, it is important to emphasize that some blueberries varieties or cultivars present difficulties on rooting, and the use of growth regulators as indolebutyric acid (IBA) are required (Schuch et al., 2007; Fischer et al., 2008, 2013; Penã et al., 2012; Marangon \& Biasi, 2013). Associated to growth regulators, the collect cuttings season, stem types, substrates and other variables can affect the cuttings rooting and root development (Schuch et al., 2007; Yamamoto et al., 2013; Colombo et al., 2018). 
A widely types of substrates can be used in horticulture to propagate plants, and the results are quite distinct (Colombo et al., 2017). Among these substrates, there are a lot of commercial mixtures based on composted pine bark, vermiculite, peat and other materials. On the other hand, some materials considerate as residues in agricultural exploration can be employed to plant propagation, such as coconut fiber, carbonized rice husk and tree bark (Yamamoto et al., 2010, 2013; Hussain et al., 2014). These materials present lower cost and are ecological, which implies in cost reduction in the nurseries production.

Considering these aspects, this study aimed to evaluate substrates and IBA application methods on 'Powderblue' blueberries minicuttings rooting as well as to verify the rooting development in different periods.

\section{Material and Methods}

\subsection{Experimental Location and Plant Material}

The trials were carried out at Londrina, Paraná, Brazil (altitude $23^{\circ} 23^{\prime} \mathrm{S}$, longitude $51^{\circ} 11^{\prime} \mathrm{W}$ and elevation of $566 \mathrm{~m}$ ). The local climate is subtropical humid, e.g. Cfa (Caviglione et al., 2000). Stock plants of 'Powderblue' blueberry (Vaccinium ashei) were cultivated in greenhouse using pots with $20 \mathrm{dm}^{3}$ of capacity. Two months before the installation of the experiments, the plants were pruned in order to form new shoots. Softwood minicuttings were used with a homogenous size of $5 \mathrm{~cm}$ length with a par of leaves cut to half.

\subsection{Substrates and IBA on Minicutting Propagation}

The first experiment was performed from March to July 2016. The basal portion of each blueberry minicutting was treated with indolebutyric acid (IBA) in $50 \%$ alcohol solution $\left(3000 \mathrm{mg} \mathrm{L}^{-1}\right)$ for 10 seconds using the quick-dip method, or with IBA diluted in talc $\left(3000 \mathrm{mg} \mathrm{kg}^{-1}\right)$. Then, ten minicuttings per plot were disposed in perforated plastic boxes $(44 \times 30 \times 7 \mathrm{~cm})$ containing pine bark, carbonized rice husk or vermiculite as rooting media, and placed in a mist chamber of a greenhouse covered with transparent polyethylene film and $30 \%$ of shading, controlled by an intermittent timer and a solenoid valve. The valve was set to mist for eight seconds each five minutes. The main physicochemical characteristics of the substrates are described in Table 1, according to Kämpf et al. (2006).

Table 1. Substrates physicochemical properties

\begin{tabular}{lllll}
\hline Substrates & $\mathrm{pH}$ & $\mathrm{EC}\left(\mu \mathrm{S} \mathrm{cm}^{-1}\right)$ & $\mathrm{BD}\left(\mathrm{kg} \mathrm{m}^{-3}\right)$ & $\mathrm{WHC}\left(\mathrm{mL} \mathrm{L}^{-1}\right)$ \\
\hline Carbonized rice husk & 6.7 & 137.0 & 149.3 & 571.7 \\
Vermiculite & 7.3 & 101.5 & 213.7 & 493.5 \\
Pine bark & 4.9 & 81.3 & 289.1 & 354.2 \\
\hline
\end{tabular}

Note. Electrical conductivity (EC), bulk density (BD) and water holding capacity (WHC).

The following characteristics were evaluated at 110 days after the experiment beginning: minicutting survival (\% of alive minicuttings, considering those with greenish color); minicutting leaf retention; sprouting minicuttings; minicuttings with callus; rooting percentage ( $\%$ of minicuttings with at least 1 root longer than $1 \mathrm{~cm}$ ); number of roots per minicutting; root length (total length of all roots per minicutting divided by the total number of roots); and fresh and dry mass of roots per minicutting $(\mathrm{mg})$. The root dry mass was obtained by the drying method in oven using forced air at $55^{\circ} \mathrm{C}$ until constant mass.

The Complete Randomized Design was used as statistical model in a $2 \times 3$ factorial arrangement, and the evaluated factors were two IBA application methods vs. three types of substrate. The dataset was submitted to analysis of variance (ANOVA) and the means were compared by Tukey's test at $\mathrm{p} \leq 0.05$ level.

\subsection{Rooting Time and IBA on Minicutting Propagation}

The substrate that promoted the best minicutings rooting performance in the first experiment was employed in the second one, which was carried out from September to December 2016. 'Powderblue' blueberry minicuttings were treated with IBA $50 \%$ alcohol solution or talc as described in the first experiment, and disposed in perforate plastic boxes filled with pine bark as substrate and placed in a mist chamber, being each plot composed by ten minicuttings.

The same evaluations previously described in the first experiment were performed in three periods, at 70, 90 and 110 days after the experiment installation (DAEI). 
The Complete Randomized Design was used as statistical model in a $2 \times 3$ factorial arrangement, and the evaluated factors were two IBA application methods vs. three rooting evaluation periods. The data recorded were submitted to analysis of variance (ANOVA) and the means were compared by Tukey's test at $\mathrm{p} \leq 0.05$ level.

\section{Results}

\subsection{Substrates and IBA on Minicutting Propagation}

A significant interaction between factors was observed in the first experiment for minicutting survival percentage (Table 2). In carbonized rice husk and vermiculite substrates, the minicuttings treated with IBA in talc presented higher survival percentage than those exposed to IBA in alcohol solution. However, the minicuttings kept in pine bark substrate were not affected by the method of IBA application.

Table 2. Survival percentage of 'Powderblue' blueberry minicuttings in response to different substrates and application methods of IBA at $3000 \mathrm{ppm}$

\begin{tabular}{llc}
\hline \multirow{2}{*}{ Substrates } & \multicolumn{2}{c}{ Minicutting survival (\%) } \\
\cline { 2 - 3 } & Talc & Alcohol \\
\hline Carbonized rice husk & $100 \mathrm{Aa}$ & $88 \mathrm{Ba}$ \\
Vermiculite & $98 \mathrm{Aa}$ & $52 \mathrm{Bb}$ \\
Pine bark & $98 \mathrm{Aa}$ & $90 \mathrm{Aa}$ \\
\hline CV $(\%)$ & 10.2 & \\
\hline
\end{tabular}

Note. Means followed by the same uppercase letter in the line or lowercase letter in the column are significantly equivalent according to Tukey's test $(\mathrm{p} \leq 0.05)$. $\mathrm{CV}=$ Coefficient of variation.

The higher minicuttings mortality rate $(48 \%)$ was recorded in vermiculite substrate, when the minicuttings were treated with IBA alcohol solution (Table 2). On the other hand, the minicuttings treated with talc presented higher survival rates in all substrates, ranged from 98 to $100 \%$.

Regarding the other analyzed characteristics, such as, minicutting leaves retention, sprouting minicuttings and rooting percentage, it was observed that the minicuttings treated with IBA in alcohol solution presented lower means in relation to those treated with talc (Table 3). Concerning to rooting percentage, a significant difference was verified among substrates; the higher percentage of rooted minicuttings occurred in pine bark substrate $(68 \%)$.

Table 3. Biometrics characteristics of 'Powderblue' blueberry minicuttings in response to different substrates and application methods of IBA at 3000 ppm

\begin{tabular}{|c|c|c|c|c|}
\hline Substrate & Sprouting minicuttings (\%) & Leaf retention (\%) & Rooting (\%) & Minicuttings with callus (\%) \\
\hline Carbonized rice husk & $44 \mathrm{a}$ & $58 \mathrm{a}$ & $41 \mathrm{~b}$ & $51 \mathrm{a}$ \\
\hline Vermiculite & $19 \mathrm{~b}$ & $36 \mathrm{~b}$ & $39 \mathrm{~b}$ & $35 \mathrm{ab}$ \\
\hline Pine bark & $48 \mathrm{a}$ & $71 \mathrm{a}$ & $68 \mathrm{a}$ & $26 \mathrm{~b}$ \\
\hline \multicolumn{5}{|l|}{ Methods } \\
\hline Talc & $47 \mathrm{a}$ & $71 \mathrm{a}$ & $67 \mathrm{a}$ & $31 \mathrm{a}$ \\
\hline Alcohol & $27 \mathrm{~b}$ & $39 \mathrm{~b}$ & $32 \mathrm{~b}$ & $43 \mathrm{a}$ \\
\hline CV $(\%)$ & 46.42 & 25.93 & 25.1 & 46.01 \\
\hline Substrate & Root number & Root length $(\mathrm{cm})$ & Roots fresh mass (mg) & Roots dry mass (mg) \\
\hline Carbonized rice husk & $3.56 \mathrm{~ns}$ & $5.78 \mathrm{~b}$ & $94.28 \mathrm{~b}$ & $11.31 \mathrm{~b}$ \\
\hline Vermiculite & 3.98 & $5.65 \mathrm{~b}$ & $92.55 \mathrm{~b}$ & $11.83 \mathrm{~b}$ \\
\hline Pine bark & 5.05 & $6.99 \mathrm{a}$ & $223.49 \mathrm{a}$ & $27.01 \mathrm{a}$ \\
\hline \multicolumn{5}{|l|}{ Methods } \\
\hline Talc & 3.79 & $6.38 \mathrm{a}$ & $153.67 \mathrm{a}$ & $18.67 \mathrm{a}$ \\
\hline Alcohol & 4.59 & $5.91 \mathrm{a}$ & $119.88 \mathrm{a}$ & $14.76 \mathrm{a}$ \\
\hline CV $(\%)$ & 34.02 & 11.44 & 53.43 & 55.67 \\
\hline
\end{tabular}

Note. $\mathrm{ns}=$ non-significant $(\mathrm{p} \leq 0.05) ; \mathrm{CV}=$ Coefficient of variation. Means followed by the same letter in the column are significantly equivalent according to Tukey's test $(\mathrm{p} \leq 0.05)$. 
On the other hand, there was not observed significant differences among the treatments for number of roots per minicutting, ranging from 3.5 to 5 ; however, the higher root length was observed in pine bark substrate, and it can be related to the physical properties of this material.

The means of fresh and dry roots mass recorded in this trial presented significant differences regarding the substrates. The minicuttings cultivated in pine bark presented higher means than those cultivated in carbonized rice husk and vermiculite (Table 3 and Figure 1). This emphasizes the importance of choose a suitable substrate to provide an adequate root system development. In contrast, the IBA application methods did not affect statistically these characteristics.
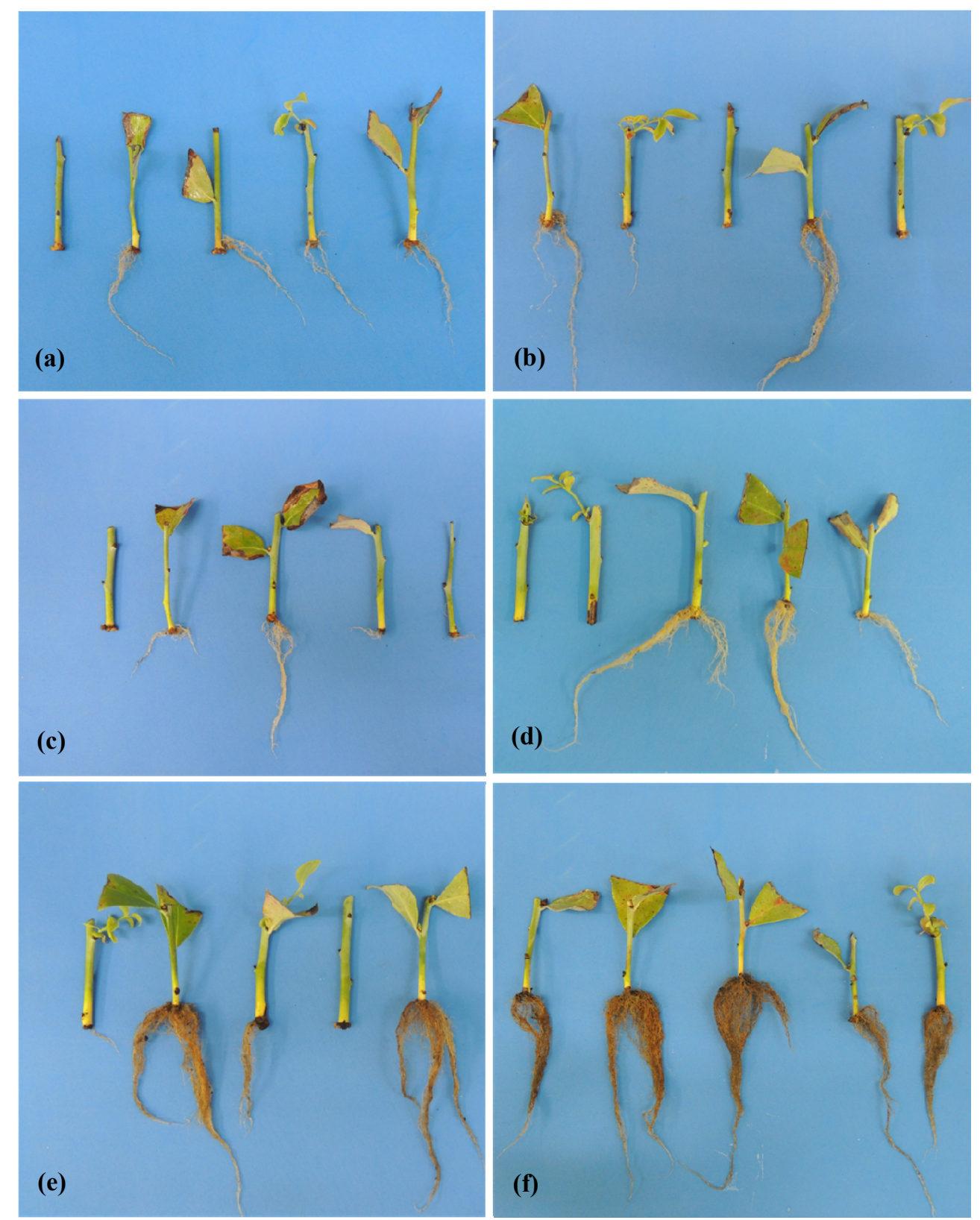

Figure 1. Rooting of 'Powderblue' blueberry minicuttings (Vaccinium ashei) in response to different substrates and IBA (3000 ppm) application methods. (a) vermiculite + IBA 50\% alcohol solution; (b) vermiculite + IBA talc powder; (c) carbonized rice husk + IBA 50\% alcohol solution; (d) carbonized rice husk + IBA talc powder; (e) pine bark + IBA 50\% alcohol solution; and (f) pine bark + IBA talc powder 


\subsection{Rooting Time and IBA on Minicutting Propagation}

In this trial, no significant interaction was verified between the factors (Tables 4 and 5), except for fresh and dry of roots mass (Table 6). The minicuttings survival percentage ranged from 99 to $100 \%$, and no significant difference among the treatments was observed. In relation to minicutting leaf retention, there was observed a decrease between the second and third evaluation period. On the other hand, a gradual and significant increase was recorded along the periods for sprouting minicuttings. Similar results were found for rooting percentage, which ranged from 55 to $84 \%$.

Table 4. Biometrics characteristics of 'Powderblue' blueberry minicuttings in different periods (days) after the experiment installation (DAEI) and in response to IBA (3000 ppm) application methods

\begin{tabular}{lllll}
\hline Seasons (days) & Minicutting survival (\%) & Sprouted minicuttings (\%) & Leaves retention (\%) & Minicuttings with callus (\%) \\
\hline 70 DAEI & $100 \mathrm{~ns}$ & $34 \mathrm{~b}$ & $79 \mathrm{a}$ & $15 \mathrm{a}$ \\
90 DAEI & 99 & $45 \mathrm{ab}$ & $83 \mathrm{a}$ & $12 \mathrm{ab}$ \\
110 DAEI & 99 & $60 \mathrm{a}$ & $56 \mathrm{~b}$ & $5 \mathrm{~b}$ \\
\hline Methods & & & $5 \mathrm{~b}$ \\
Talc & 100 & $51 \mathrm{a}$ & $77 \mathrm{a}$ & $16 \mathrm{a}$ \\
Alcohol & 99 & $41 \mathrm{a}$ & $68 \mathrm{a}$ & 76.55 \\
\hline CV $(\%)$ & 2.60 & 31.65 & 23.97 & \\
\hline
\end{tabular}

Note. Means followed by the same letter in the column are significantly equivalent according to Tukey's test ( $\mathrm{p} \leq$ $0.05)$. $\mathrm{ns}=$ non-significant $(\mathrm{p} \leq 0.05) ; \mathrm{CV}=$ Coefficient of variation.

Table 5. Biometrics characteristics of 'Powderblue' blueberry minicuttings at different periods (days) after the experiment installation (DAEI) and in response to IBA (3000 ppm) application methods

\begin{tabular}{llll}
\hline Seasons (days) & Rooting (\%) & Root number & Root length $(\mathrm{cm})$ \\
\hline 70 DAEI & $55 \mathrm{~b}$ & $6.84 \mathrm{~ns}$ & $3.51 \mathrm{~b}$ \\
90 DAEI & $70 \mathrm{ab}$ & 7.20 & $5.25 \mathrm{a}$ \\
110 DAEI & $84 \mathrm{a}$ & 7.06 & $5.53 \mathrm{a}$ \\
\hline Methods & $73 \mathrm{a}$ & 7.55 & $4.91 \mathrm{a}$ \\
Talc & $66 \mathrm{a}$ & 6.52 & $4.61 \mathrm{a}$ \\
Alcohol & 22.70 & 32.31 & 12.04 \\
\hline CV $(\%)$ & . & & \\
\hline
\end{tabular}

Note. Means followed by the same letter in the column are significantly equivalent according to Tukey's test ( $\mathrm{p} \leq$ $0.05) . \mathrm{ns}=$ non-significant $(\mathrm{p} \leq 0.05) ; \mathrm{CV}=$ Coefficient of variation.

Concerning the IBA application methods, minicuttings treated with talc rooted $10 \%$ more than the minicuttings treated with $50 \%$ alcohol solution, and the minicuttings treated with $50 \%$ alcohol solution presented around $10 \%$ more callus than those treated with talc. Significant differences were record only for percentage of minicuttings with callus.

Significant interaction between evaluation periods and IBA application methods are shown in Table 6 for fresh and dry roots mass. It is possible to observe similar results for both characteristics, i.e., higher fresh and dry roots mass was noticed on the longest period for minicuttings treated with IBA in talc. Comparing IBA application methods to dry root mass, the minicuttings treated with talc presented almost two times more dry mass than those treated with IBA in alcohol solution, resulting in better quality of root system. 
Table 6. Biometrics characteristics of 'Powderblue' blueberry minicuttings at different periods (days) after the experiment installation (DAEI) and in response to IBA (3000 ppm) application methods

\begin{tabular}{|c|c|c|c|c|}
\hline \multirow{2}{*}{ Seasons (days) } & \multicolumn{2}{|c|}{ Roots fresh mass (mg) } & \multicolumn{2}{|c|}{ Roots dry mass (mg) } \\
\hline & Talc & Alcohol & Talc & Alcohol \\
\hline 70 DAEI & $122.65 \mathrm{Ab}$ & $75.49 \mathrm{Ab}$ & $13.90 \mathrm{Ab}$ & $12.16 \mathrm{Ab}$ \\
\hline 90 DAEI & $156.33 \mathrm{Ab}$ & $187.71 \mathrm{Aa}$ & $25.32 \mathrm{Aa}$ & $26.19 \mathrm{Aa}$ \\
\hline 110 DAEI & $263.01 \mathrm{Aa}$ & 147.55 Bab & $32.06 \mathrm{Aa}$ & $17.46 \mathrm{Bab}$ \\
\hline $\mathrm{CV}(\%)$ & 39.71 & & 33.18 & \\
\hline
\end{tabular}

Note. Means followed by the same uppercase letter in the line or lowercase letter in the column are significantly equivalent according to Tukey's test $(\mathrm{p} \leq 0.05)$. $\mathrm{CV}=$ Coefficient of variation.

The rooting potential can be related to the period that the minicuttings are kept in contact with the substrate (Figure 2); and this fact can be proved by a decrease in the percentage of cuttings with callus, once these characteristics were inversely proportional. No significant difference was observed among the treatments regarding the root number per minicutting, as previously reported in the first trial. The root length increased between the first and second periods due to the higher period that minicuttings were kept on pine bark substrate.
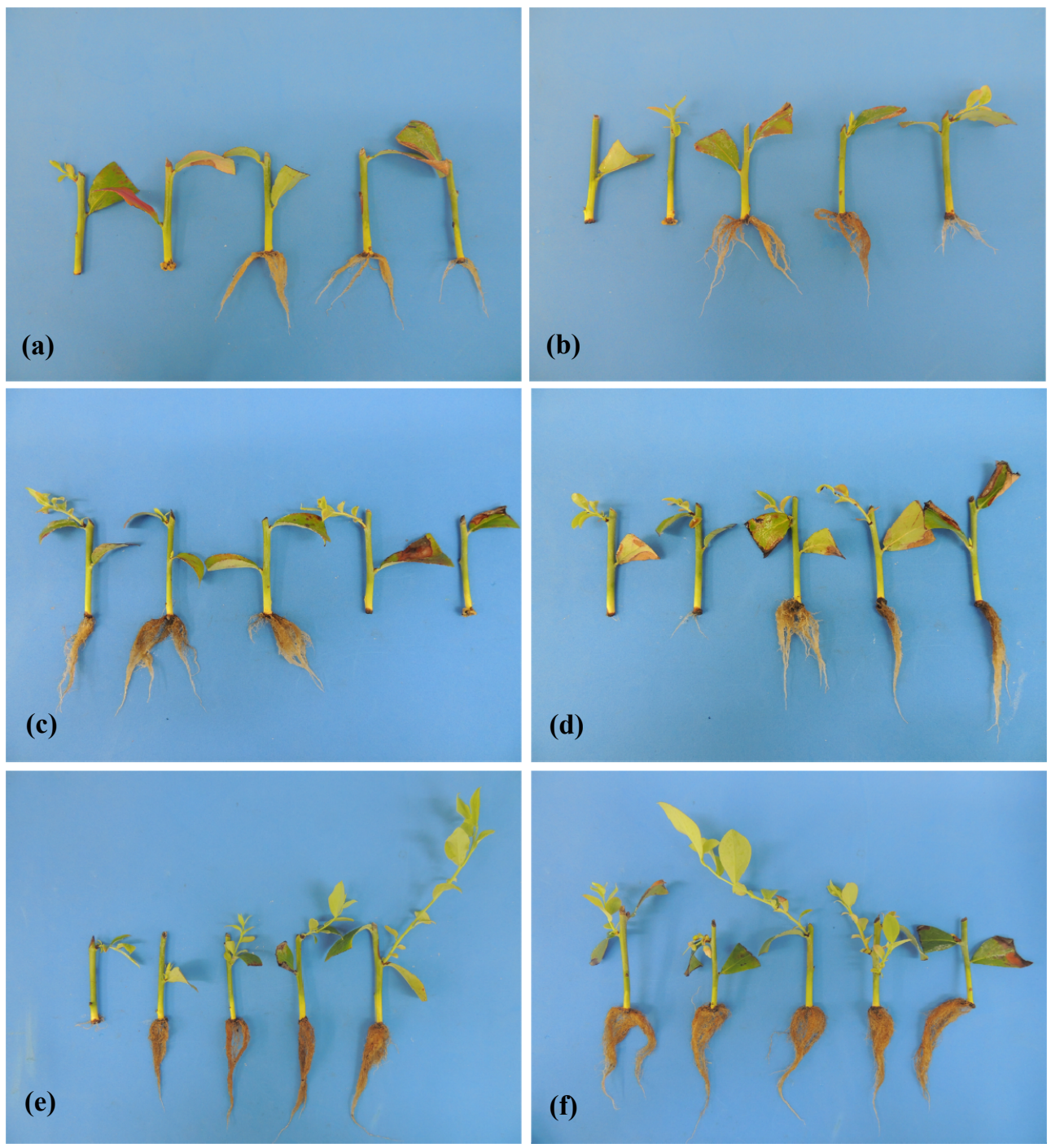

Figure 2. Rooting of 'Powderblue' blueberry minicuttings (Vaccinium ashei) at different periods (days) after the experiment installation (DAEI) and in response to IBA (3000 ppm) application methods. (a) 70 DAEI + IBA 50\% alcohol solution; (b) 70 DAEI + IBA talc powder; (c) 90 DAEI + IBA 50\% alcohol solution; (d) 90 DAEI + IBA talc powder; (e) 110 DAEI + IBA 50\% alcohol solution; and (f) 110 DAEI + IBA talc powder 


\section{Discussion}

The different results on blueberries rooting percentage recorded by some authors for the same species or cultivars can be related to growth regulators use (type, concentration and application methods); collection season and vegetative stage of stock plants; substrates (since different materials presents different physicochemical properties); and period to access the rooting performance, as observed in the second trial.

The rooting percentage of 'Climax' blueberry cuttings ranged from 34.6 to $50.6 \%$ in experiments carried out by Hoffmann et al. (1995) and Peña et al. (2012), respectively; and according to Peña et al. (2012) the differences observed are due to the period that the rooting was accessed. However, for the same cultivar, regardless the IBA use, 19 and $82 \%$ of rooting was recorded by Trevisan et al. (2008) and Fischer et al. (2008), respectively. So, these results can confirm the complexity involved on cutting rooting and shows the need for more enlightening and complete studies.

In the first experiment, there was recorded for vermiculite that the minicuttings treated with IBA alcohol solution presented higher mortality rate, and this result can reflect directly on the rooting percentage results. On the other hand, the higher rooting percentage was verified on pine bark substrate when the minicuttings were treated with IBA in talc. In the second experiment, the rooting percentage reached $84 \%$ at 110 days after the experiment installation, regardless the IBA application method. However, the IBA concentration used in this study may have caused some phytotoxic effect on 'Powderblue' minicuttings, since the concentration of $2000 \mathrm{mgL}^{-1}$ provided 96 to $98 \%$ of minicuttings rooting for the same cultivar (Fischer et al., 2013).

Regardless substrates and IBA application methods, there was observed in the first trial a positive and high correlation between minicuttings leaf retention and rooting percentage $(+0.83)$. This information is important since some authors have reported that the leaf retention can support the cuttings rooting; according to them, leaves can transport auxins and other metabolic compounds to cuttings basal portion and stimulate the rooting process (Fachinello et al., 2005; Hartmann et al., 2011). The leaves that remain in the cuttings are also responsible to increase the transpiration rates, and this process can keep the cuttings in high hydration levels once there is available water in the substrates, due to the capillary water movement in the xylem vessels, maintaining active the cuttings metabolic activities (Ristow et al., 2011; Fischer et al., 2013).

Besides the rooting percentage, there are other characteristics that should be considered for plants propagation of high quality, such as sprouting cuttings and roots system development. In both experiments, the percentage of sprouting cuttings was around 50-60\% when cultivated in pine bark substrate. For Vaccinium ashei 'Climax' and Vaccinium ashei 'Florida' blueberries, the sprouting cuttings percentage was close to $50 \%$, regardless IBA concentration and application methods (Peña et al., 2012).

A well-developed root system is important to reduce the nursery mortality in the field, soon after the transplant operation. The number of roots per cutting recorded in both experiments are in agreement to those reported by Maragon and Biasi (2013), 7.5 roots per cuttings, in similar periods when this characteristic was accessed.

Regarding the root length obtained in the first experiment, the mean was slightly higher than those observed in the second one. On the other hand, the number of roots recorded in the second experiment was higher than the first one; it occurred possibly due to compensation between the number of roots and root length.

In the present study, there was higher water content available in the substrates because of the mist chamber system adopted, and the carbonized rice husk and vermiculite presented higher water hold capacity than pine bark (Table 1). However, a good root development also depends on the physicochemical substrates properties and its management. According to Verdonck et al. (1981), and Couvillon (1998), an ideal substrate is one which retains a sufficient water content to avoid the cuttings base dehydratation and, once saturated, presents adequate pore space to facilitate rooting and prevent diseases growth. Similarly, it is important to provide a substrate with adequate chemical properties such as $\mathrm{pH}$, as long as substrates acidity or alkalinity may interact with the cuttings base and promotes different responses (Hartmann et al., 2011). In study ranging sand $\mathrm{pH}$ values from 3.5 to 6.5 to promote Myrciaria jaboticaba rooting, there was observed a substantial cutting rooting in $\mathrm{pH} 4.5$ to 5.5 (Pereira et al., 2005). Therefore, among other factors, the air/water ratio and the $\mathrm{pH}$ (4.9) recorded for pine bark were better to promote minicuttings rooting comparing to vermiculite and carbonized rice husk.

It is also important to highlight that minicuttings are an excellent alternative to maximize the use of propagation material, since it presents a reduced size in relation to conventional cuttings. Regarding the IBA application method, the powder (talc) can be more efficient because it promotes longer adherence of the growth regulator on the cuttings base. Also, the talc adherence permits to verify if the growth regulator was applied on the cuttings, in case of the cuttings do not rooting. 


\section{Conclusion}

To produce 'Powderblue' blueberry nursery from minicuttings, it is recommended to use pine bark as substrate and talc powder as IBA $(3000 \mathrm{ppm})$ application method. At 110 days after the planting, the minicuttings rooted in pine bark presents a well-developed root system.

\section{References}

Caviglione, J. H., Kiihl, L. R. B., Caramori, P. H., \& Oliveira, D. (2000). Cartas climáticas do Paraná. Retrieved from http://www.iapar.br/modules/conteudo/conteudo.php?conteudo=677

Colombo, R. C., Favetta, V., Cruz, M. A., Carvalho, D. U., Roberto, S. R., \& Faria, R. T. (2017). Acclimatization and growth of ornamental pineapple seedlings under organic substrates. Ornamental Horticulture, 23, 257-262. https://doi.org/10.14295/oh.v23i3.1040

Colombo, R. C., Assis, A. M., Favetta, V., Yamamoto, L. Y., \& Roberto, S. R. (2018). Collect seasons, indolebutyric acid and substrates on rooting of 'Bengal' lychee cuttings. Journal of Agriculture Science, 10, 338-344. https://doi.org/10.5539/jas.v10n5p338

Couvillon, G. A. (1998). Rooting responses to different treatments. Acta Horticulturae, 227, 187-196. https://doi.org/10.17660/ActaHortic.1988.227.30

Fachinello, J. C., Hoffmann, A., Nachtigal, J. C., Kersten, E., \& Fortes, G. R. L. (2005). Propagação de plantas frutiferas. Brasília: Embrapa Informações Tecnológicas.

Fischer, D. L., Fachinello, J. C., Antunes, L. E., Tomaz, Z. F. P., \& Giacobbo, C. L. (2008). Effect of indolebutyric acid and cultivar on rooting of hardwood cuttings of blueberry. Revista Brasileira de Fruticultura, 30, 285-289. https://doi.org/10.1590/S0100-29452008000200003

Fischer, D. L. O., Vignolo, G., Aldrighi, M., Fachinello, J. C., \& Antunes, L. E. C. (2012). Rooting of blueberry hardwood cuttings as affected by wood type. Acta Horticulturae, 926, 273-277. https://doi.org/10.17660/ ActaHortic.2012.926.37

Fischer, D. L. O., Fachinello, J. C., Antunes, L. E. C., Fischer, C., \& Giacobbo, C. L. (2013). Rooting of blueberry minicuttings. Revista de la Facultad de Agronomía, 112, 1-5. Retrieved from http://revista. agro.unlp.edu.ar/index.php/revagro/article/view/48/27

González, M., López, M., Valdes, A., \& Rojas, R. (2000). Micropropagation of three berry fruit species using nodal segments from field-grown plants. Annals of Applied Biology, 137, 073-078. https://doi.org/ 10.1111/j.1744-7348.2000.tb00059.x

Hartmann, H. T., Kester, D. E., Davies Júnior, F. T., \& Geneve, R. L. (2011). Plant propagation: Principles and practices. New Jersey: Prentice Hall.

Hoffmann, M. R., Martin, S. T., Choi, W., \& Bahnemann, D. W. (1995). Environmental Applications of Semiconductor Photocatalysis. Chemical Reviews, 95, 69-96. https://doi.org/10.1021/cr00033a004

Hussain, I., Assis, A. M., Yamamoto, L. Y., Koyama, R., \& Roberto, S. R. (2014). Indole butyric acid and substrates influence on multiplication of blackberry 'Xavante'. Ciência Rural, 44, 1761-1765. https://doi.org/10.1590/0103-8478cr20131204

Kämpf, A. N., Takane, R. J., \& Siqueira, P. T. V. (2006). Floricultura: Técnicas de preparo de substratos. Brasília: LK.

Marangon, A. M., \& Biasi, L. A. (2013). Estaquia de mirtilo nas estações do ano com ácido indolbutírico e aquecimento do substrato. Pesquisa Agropecuária Brasileira, 48, 25-32. https://doi.org/10.1590/S0100-204 X2013000100004

Meiners, J., Schwab, M., \& Szankowski, I. (2007). Efficient in vitro regeneration systems for Vaccinium species. Plant Cell, Tissue and Organ Culture, 89, 169-176. https://doi.org/10.1007/s11240-007-9230-7

Ostrolucká, M., Libiaková, G., Ondrušková, E., \& Gajdošová, A. (2004). In vitro propagation of Vaccinium species. Acta Universitatis Latviensis, Biology, 676, 207-212. Retrieved from http://eeb.lu.lv/EEB/2004/ Ostrolucka.pdf

Pelizza, T. R., Carvalho, G. L., \& Schuch, M. W. (2010). Growth evaluation of blueberry minicuttings under different growth regulators. Acta Horticulturae, 884, 623-628. https://doi.org/10.17660/ActaHortic.2010. 884.82 
Peña, M. L. P., Gubert, C., Tagliani, M. C., Bueno, P. M. C., \& Biasi, L. A. (2012). Concentrations and forms of application of indolebutyric acid on cutting propagation of cvs. Flórida and Clímax blueberries. Semina: Ciências Agrárias, 33, 57-64. https://doi.org/10.5433/1679-0359.2012v33n1p57

Pereira, M., Oliveira, A. L., Gonçalves, A. N., \& Almeida, M. (2005). Substract, pH values and IBA concentrations effects on rooting of apical cuttings of jabuticaba [Myrciaria jaboticaba (Vell.) O. Berg] trees. Scientia Forestalis, 69, 84-92.

Ristow, N. C., Antunes, L. E. C., Shuch, M. W., Trevisan, R., \& Carpenedo, S. (2009). Crescimento de plantas de mirtilo a partir de mudas micropropagadas. Revista Brasileira de Fruticultura, 31, 210-215. https://doi.org/ $10.1590 / \mathrm{S} 0100-29452009000100029$

Ristow, N. C., Antunes, L. E. C., Carpenedo, S., \& Schuch, M. W. (2011). Diferentes substratos na produção de mudas de mirtileiro. Ciência Rural, 41, 1154-1159. https://doi.org/10.1590/S0103-84782011005000091

Schuch, M. W., De Rossi, A., Damiani, C. R., \& Soares, G. C. (2007). AIB e substrato na produção de mudas de mirtilo cv. 'Climax' através de microestaquia. Ciência Rural, 37, 1446-1449. https://doi.org/10.1590/ S0103-84782007000500036

Schuch, M. W., Damiani, C. R., Silva, L. C., \& Erig, A. C. (2008). Micropropagação como técnica de rejuvenescimento em mirtilo (Vaccinium ashei Reade) cultivar Climax. Ciênc. Agrotec., 32, 814-820. https://doi.org/10.1590/S1413-70542008000300017

Silva, L. C., Schuch, M. W., Souza, J. A., Erig, A. C., \& Antunes, L. E. C. (2006). Meio nutritivo, reguladores de crescimento e frio no estabelecimento in vitro de mirtilo (Vaccinium ashei Reade) cv. Delite. R. Bras. Agrociência, 12, 405-408.

Silva, L. C., Schuch, M. W., Souza, J. A., Erig, A. C., \& Antunes, L. E. C. (2007). Efeito da iluminação e pré-lavagem das brotações de mirtilo cv.Florida no estabelecimento in vitro. R. Bras. Agrociência, 13, 127-129.

Trevisan, R., Franzon, R., Neto, R., Silva, R., Dias, G., \& Corrêa, A. (2008). Enraizamento de estacas herbáceas de mirtilo: Influência da lesão na base e do ácido indolbutírico. Ciência e Agrotecnologia, 32, 402-406. https://doi.org/10.1590/S1413-70542008000200009

Verdonck, O., De Vleeschauwer, D., \& De Boodt, M. (1981). The influence of the substrate to plant growth. Acta Horticulturae, 126, 251-258. https://doi.org/10.17660/ActaHortic.1982.126.30

Yamamoto, L. Y., Borges, R. S., Sorace, M., Rachid, B. F., Ruas, J. M. F., Sato, O., ... Roberto, S. R. (2010). Enraizamento de estacas de Psidium guajava L. 'Século XXI' tratadas com ácido indolbutírico veiculado em talco e álcool. Ciência Rural, 40, 1037-1042. https://doi.org/10.1590/S0103-84782010000500006

Yamamoto, L. Y., Koyama, R., Borges, W. F. S., Antunes, L. E. C., Assis, A. M., \& Roberto, S. R. (2013). Substrates on rooting of blackberry 'Xavante' herbaceous cuttings. Ciência Rural, 43, 15-20. https://doi.org/10.1590/S0103-84782012005000135

\section{Copyrights}

Copyright for this article is retained by the author (s), with first publication rights granted to the journal.

This is an open-access article distributed under the terms and conditions of the Creative Commons Attribution license (http://creativecommons.org/licenses/by/4.0/). 